\title{
Clinical Neuroendocrinology
}

\section{Biochemical Predictors of Outcome of Pituitary Surgery for Cushing's Disease}

\author{
R.A. Alwani ${ }^{\mathrm{a}}$ W.W. de Herder ${ }^{\mathrm{a}} \quad$ M.O. van Aken ${ }^{\mathrm{a}} \quad$ J.H. van den Berge ${ }^{\mathrm{b}}$ \\ E.J. Delwel $^{b} \quad$ A.H.G. Dallenga ${ }^{b}$ F.H. De Jong ${ }^{a}$ S.W.J. Lamberts ${ }^{a}$ \\ A.J. van der Lely ${ }^{a}$ R.A. Feelders ${ }^{a}$ \\ ${ }^{a}$ Department of Internal Medicine, Division of Endocrinology, and ${ }^{b}$ Department of Neurosurgery, \\ Erasmus Medical Centre, Rotterdam, The Netherlands
}

\section{Key Words}

Cushing's disease $\cdot$ Pituitary adenoma $\cdot$ Pituitary surgery • Cortisol $\cdot$ Metyrapone $\cdot$ Corticotropin-releasing hormone

\begin{abstract}
Objective: Transsphenoidal surgery (TS) is the primary therapy for Cushing's disease (CD). The aims of this retrospective study were twofold: (i) investigate early and late results of TS for CD, and (ii) evaluate various postoperative tests in order to predict the outcome of TS. Methods: We reviewed the long-term outcome in 79 patients with $C D$ who underwent TS (median follow-up 84 months, range 6-197). Within 2 weeks after surgery, morning serum cortisol concentrations were obtained $(n=78)$ and corticotropin-releasing hormone $(\mathrm{CRH})(\mathrm{n}=53)$ and metyrapone tests $(n=72)$ were performed. Three groups of outcome were identified: sustained remission, early failure (persistent $C D$ ), and late relapse. $\boldsymbol{R} \boldsymbol{e}$ sults: Immediate postoperative remission was achieved in 51 patients $(65 \%)$, whereas 28 patients $(35 \%)$ had persistent $\mathrm{CD}$ after TS. Ten patients developed recurrent $\mathrm{CD}$ after initial remission (20\%). Morning cortisol: all relapses but one recorded serum cortisol $>50 \mathrm{nmol} / \mathrm{l}$. A cortisol threshold value of $200 \mathrm{nmol} / \mathrm{l}$ has a positive predictive value of $79 \%$ for immediate surgical failure (negative predictive failure [NPV] 97\%).
\end{abstract}

CRH test: $\mathrm{CRH}$-stimulated peak cortisol $\geq 600 \mathrm{nmol} / \mathrm{l}$ predicted early failure in $78 \%$ (NPV $100 \%$ ). All relapses recorded $\mathrm{CRH}$-stimulated peak cortisol $\geq 485 \mathrm{nmol} / \mathrm{l}$. Metyrapone test: 11-deoxycortisol $\geq 345 \mathrm{nmol} / /$ predicted an early failure in $86 \%$ of cases (NPV 94\%). Conclusion: Predictive factors of surgical failure are morning cortisol $\geq 200 \mathrm{nmol} / \mathrm{l}, 11$-deoxycortisol $\geq 345 \mathrm{nmol} / \mathrm{l}$ after metyrapone and $\mathrm{CRH}$-stimulated cortisol $\geq 600 \mathrm{nmol} / \mathrm{l}$. CRH and/or metyrapone testing are not superior to morning cortisol concentration in the prediction of outcome of TS. Careful long-term follow-up remains necessary independent of the outcome of biochemical testing.

Copyright $\odot 2009$ S. Karger AG, Basel

\section{Introduction}

Cushing's disease (CD) is caused by adrenocorticotropin (ACTH)-secreting pituitary tumors. Transsphenoidal surgery (TS) is the first choice of treatment for CD. Although being a safe treatment, with a reported 30-day mortality in experienced hands of less than $1 \%$, surgical cure is not achieved in all patients [1-3]. The reported initial success rate for pituitary surgery for $\mathrm{CD}$ varies between 60 and $86 \%$, however the true rate tends to be low-

\section{KARGER}

Fax +4161306 1234

E-Mail karger@karger.ch

www.karger.com
(C) 2009 S. Karger AG, Basel

$0028-3835 / 10 / 0912-0169 \$ 26.00 / 0$

Accessible online at:

www.karger.com/nen
Rehmat A. Alwani, MD

Department of Internal Medicine, Division of Endocrinology

Erasmus Medical Centre, Room H555, PO Box 2040

NL-3000 CA Rotterdam (The Netherlands)

Tel. +31 107040 704, Fax +31 104 63639, E-Mail r.alwani@erasmusmc.nl 
Table 1. Patient characteristics of 79 patients with Cushing's disease

\begin{tabular}{|c|c|c|c|}
\hline & $\begin{array}{l}\text { Sustained } \\
\text { remission } \\
(\mathrm{n}=41)\end{array}$ & $\begin{array}{l}\text { Early } \\
\text { failure } \\
(\mathrm{n}=28)\end{array}$ & $\begin{array}{l}\text { Late } \\
\text { relapse } \\
(\mathrm{n}=10)\end{array}$ \\
\hline Mean age in years (SE) & $42.3 \pm 2.0$ & $39.9 \pm 2.5$ & $38.3 \pm 4.0$ \\
\hline \multicolumn{4}{|l|}{ Sex } \\
\hline Male & 11 & 4 & 1 \\
\hline Female & 30 & 24 & 9 \\
\hline Mean follow-up months (SE) & $75.9 \pm 7.2$ & $91.9 \pm 10.2$ & $120.9 \pm 19.8$ \\
\hline Deaths & 4 & 3 & 1 \\
\hline Lost to follow-up & 4 & 1 & 1 \\
\hline \multicolumn{4}{|l|}{ Adenoma on MRI } \\
\hline Macroadenoma & 7 & 12 & 2 \\
\hline Microadenoma & 34 & 16 & 8 \\
\hline Visible & 27 & 10 & 7 \\
\hline Non-visible & 7 & 6 & 1 \\
\hline BIPSS & 17 & 12 & 3 \\
\hline \multicolumn{4}{|l|}{ Pretreatment } \\
\hline Ketoconazole & 31 & 23 & 5 \\
\hline Metyrapone & 0 & 1 & 0 \\
\hline \multicolumn{4}{|c|}{ Postoperative pituitary insufficiency } \\
\hline No hormonal deficiency & 31 & 19 & 7 \\
\hline 1 axis & 4 & 4 & 2 \\
\hline 2 axes & 3 & 4 & 1 \\
\hline 3 or more axes & 3 & 1 & 0 \\
\hline Morning cortisol $(\mathrm{n}=78)$ & 40 & 28 & 10 \\
\hline$\leq 50 \mathrm{nmol} / \mathrm{l}$ & 18 & 0 & 1 \\
\hline $50-200 \mathrm{nmol} / \mathrm{l}$ & 15 & 1 & 5 \\
\hline$>200 \mathrm{nmol} / \mathrm{l}$ & 7 & 27 & 4 \\
\hline Metyrapone test $(n=72)$ & 37 & 27 & 8 \\
\hline 11-deox $<50 \mathrm{nmol} / \mathrm{l}$ & 18 & 0 & 2 \\
\hline 11-deox 50-150 nmol/1 & 8 & 0 & 1 \\
\hline 11-deox 150-350 nmol/1 & 7 & 3 & 3 \\
\hline 11-deox >350 nmol/1 & 4 & 24 & 2 \\
\hline CRH test $(\mathrm{n}=53)$ & 32 & 18 & 3 \\
\hline Max. cortisol $\leq 600 \mathrm{nmol} / 1$ & 27 & 0 & 2 \\
\hline Max. cortisol $>600 \mathrm{nmol} / \mathrm{l}$ & 5 & 18 & 1 \\
\hline Max. ACTH $\leq 10 \mathrm{pmol} / 1$ & 22 & 3 & 0 \\
\hline Max. ACTH > $10 \mathrm{pmol} / 1$ & 2 & 9 & 2 \\
\hline
\end{tabular}

er since up to $25 \%$ of patients suffer from recurrence after apparent remission [4-12]. Moreover, success and recurrence rates per center largely depend on biochemical criteria which can differ per center. Immediately after successful resection of the autonomous corticotropic adenoma, the remaining corticotropic cells are still suppressed in the majority of patients. Therefore, low or undetectable postoperative serum cortisol levels are associated with long-term remission $[1,6,12-16]$. Inability to increase the secretion of ACTH (and subsequently 11-deoxycortisol secretion) after administration of metyrapone, an $11 \beta$ - hydroxylase (CYP11B1) blocker, may also indicate complete surgical excision of the pituitary adenoma [17]. Since corticotropic pituitary adenomas are generally susceptible to stimulation by corticotropin-releasing hormone $(\mathrm{CRH})$, responsiveness to $\mathrm{CRH}$ in the early postoperative phase may reflect incomplete resection of adenoma and an increased risk of recurrence $[6,7,18-21]$.

The objective of this survey was twofold: (i) to investigate the early and late results of pituitary surgery for CD, and (ii) to compare the predictive values of three early postoperative tests (morning serum cortisol concentration, $\mathrm{CRH}$ test, and metyrapone test) in the individual assessment of outcome defined by 24-hour urinary free cortisol (UFC) excretion and $1 \mathrm{mg}$ overnight dexamethasone testing at 12 weeks after pituitary surgery.

\section{Patients and Methods}

\section{Patients}

Seventy-nine consecutive patients underwent primary pituitary surgery for CD at the Erasmus Medical Centre Rotterdam between 1991 and 2006. We reviewed our data retrospectively. The study was approved as an institutional case-note review. The mean age of patients at the time of surgery was 40.8 years (SE 1.46). The median follow-up period was 84 months (range 7-121). Sixty-three patients were female (80\%). Clinical characteristics of patients are detailed in table 1.

All patients were diagnosed preoperatively with CD according to the following criteria: clinical features, elevated excretion of free cortisol in 24-hour urine samples on at least two occasions, insufficient suppression of serum cortisol after $1 \mathrm{mg}$ overnight dexamethasone (cutoff $50 \mathrm{nmol} / \mathrm{l}$ ), loss of normal circadian rhythm of cortisol secretion and non-suppressed plasma ACTH levels in the presence of normal or elevated serum cortisol levels. Radiological imaging of the pituitary was performed by magnetic resonance imaging (MRI). Macroadenoma was defined as a pituitary tumor with a diameter of $>1 \mathrm{~cm}$ in any dimension on radiological imaging [22]. Pituitary adenomas not visible on preoperative MRI or adenomas $<1 \mathrm{~cm}$ in diameter were classified as microadenomas. The study population consisted of 21 patients with macroadenomas and 58 patients with microadenomas. Fourteen microadenomas could not be visualized preoperatively by MRI. Bilateral inferior petrosal sinus sampling (BIPSS) was performed if the size of the adenoma was $<6 \mathrm{~mm}$, or if no adenoma was present on radiological imaging. Basal bilateral petrosal sinus-to-peripheral plasma ACTH ratio of $>2.0$ or post-CRH stimulation ratio $\geq 3.0$ were used to demonstrate pituitary ACTH hypersecretion [23].

Presurgical treatment with adrenal enzyme inhibitors, such as ketoconazole $(n=59)$ and metyrapone $(n=1)$, was given during 3 months until 1 day before pituitary surgery. Four different neurosurgeons operated on the patients in our series. A transsphenoidal selective adenomectomy was performed when the tumor was radiologically identified or, in cases of negative sellar imaging, hemihypophysectomy was performed on the side with ACTH lat- 
Table 2. Clinical characteristics of patients who died $(n=8)$ and who were lost to follow-up $(n=6)$

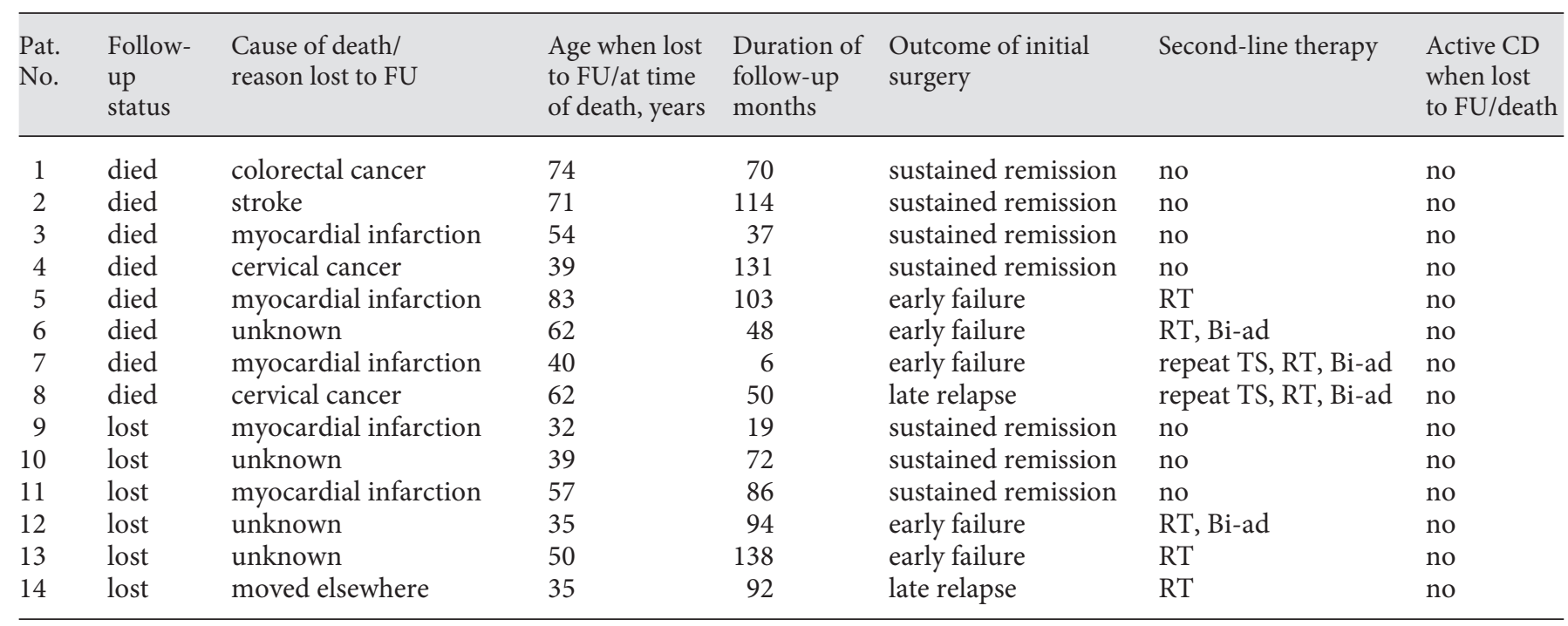

FU = Follow-up; $\mathrm{CD}=$ Cushing's disease; $\mathrm{TS}$ = transsphenoidal surgery; $\mathrm{RT}$ = radiotherapy; Bi-ad = bilateral adrenalectomy.

eralization during BIPSS. On the day of surgery the patients received $200 \mathrm{mg}$ of hydrocortisone, which was tapered off to no dose within 4 days. In 1 patient, hydrocortisone could not be tapered postoperatively due to severe glucocorticoid withdrawal symptoms, such as fatigue, nausea and hypotension. All patients received antibiotic prophylaxis (amoxicillin) in the perioperative period $[24,25]$.

\section{Postoperative Assessment}

Between days 7 and 10 postoperatively, morning serum cortisol $(\mathrm{n}=78)$ was measured at $08: 00 \mathrm{~h}, 72 \mathrm{~h}$ after the last dose of hydrocortisone. Subsequently, a metyrapone test $(n=72)$ and, from 1998 onwards, a CRH test $(n=53)$ were performed in the following days. Human CRH (Ferring BV, Hoofddorp, The Netherlands) was used during the CRH test. At 07:00 h, an indwelling forearm cannula was inserted and $30 \mathrm{~min}$ later $1 \mu \mathrm{g} / \mathrm{kg} \mathrm{CRH}$ was administered intravenously. Serum cortisol was measured at 15min intervals for $2 \mathrm{~h}$. Plasma ACTH was also measured in $38 \mathrm{pa}-$ tients at 15 -min intervals for $2 \mathrm{~h}$. During the CRH test, patients were restricted to bed rest. The metyrapone stimulation test was performed after an overnight fast. The metyrapone stimulation test is routinely performed in our hospital after pituitary surgery in order to test the ACTH reserve. Following the measurement of morning serum cortisol, patients received 6 oral doses of $750 \mathrm{mg}$ metyrapone (Alliance Pharmaceuticals Ltd, Chippenham, Wilts., $\mathrm{UK})$ at 4 -hour intervals. On the second day of the test, a fasting blood sample was taken for determination of 11-deoxycortisol, $4 \mathrm{~h}$ after the last metyrapone dose [17]. Pending the results of the postoperative tests, patients were discharged on hydrocortisone replacement therapy (40 mg/day). Patients who recorded 11-deoxycortisol levels $<350 \mathrm{nmol} / \mathrm{l}$ in the metyrapone test were considered to have secondary adrenal insufficiency and continued hydrocortisone replacement therapy until further notice [26]. Clinical remission was defined as a continued need for cortico- steroid replacement for $>6$ months after TS. Biochemical remission was defined as suppression of serum cortisol $<50 \mathrm{nmol} / \mathrm{l}$ after $1 \mathrm{mg}$ overnight dexamethasone and a normal UFC excretion (reference $<850 \mathrm{nmol} / 24 \mathrm{~h}$ ). All patients in remission after surgery (both clinical and biochemical remission) had resolution of symptoms of CD (weight loss, improvement of glucose tolerance, hypertension and emotional lability). Three groups of outcome were identified: sustained remission, early failure (persistent CD), and late relapse (recurrence of disease after initial remission). During follow-up all patients were re-evaluated initially at 12 weeks after surgery, followed by 6-monthly intervals in the first 2 years after surgery and at least annually thereafter. Endocrine evaluation consisted of measurement of serum cortisol after $1 \mathrm{mg}$ overnight dexamethasone and $24 \mathrm{~h}$ UFC excretion along with assessment of anterior pituitary hormone function. Hypopituitarism was defined as the presence of hypothyroidism, hypogonadism, growth hormone deficiency or permanent diabetes insipidus. Patients were considered to be growth hormone-deficient if serum insulin-like growth factor-1 levels were below the normal range at two different intervals or when an impaired response was seen during growth hormone stimulation tests. Eight patients died during follow-up. Causes of death were cardiovascular events and stroke (4 patients), colorectal cancer (1 patient), cervical cancer (1 patient) and unknown (2 patients). Six patients were lost to follow-up in the study period. None of the patients who died or who were lost to follow-up during the study period suffered from active CD (table 2).

\section{Laboratory Assays}

Serum cortisol and 24-hour UFC excretion were measured using a chemiluminescence-based immunoassay (Immulite 2000, Siemens, Los Angeles Calif., USA; inter- and intra-assay coefficients of variation, respectively below 15 and 7\%). Urines were analyzed without prior solvent extraction. 


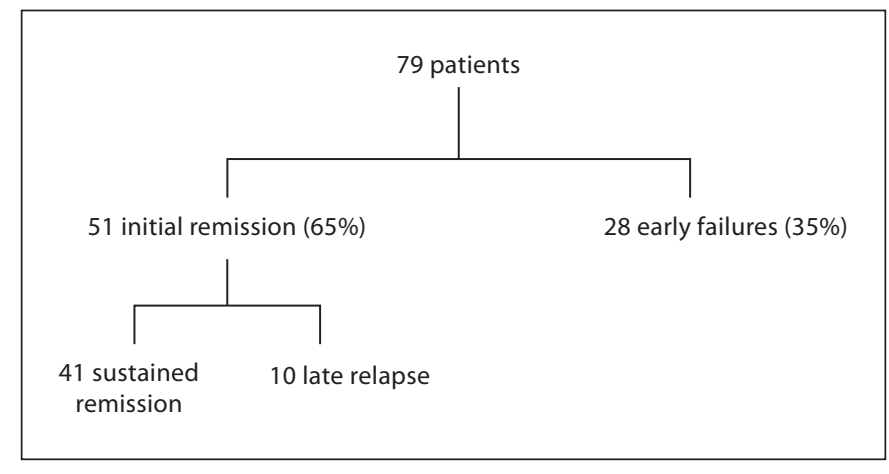

Fig. 1. Clinical outcome of TS for CD in the Erasmus Medical Centre Rotterdam, The Netherlands (1991-2006).

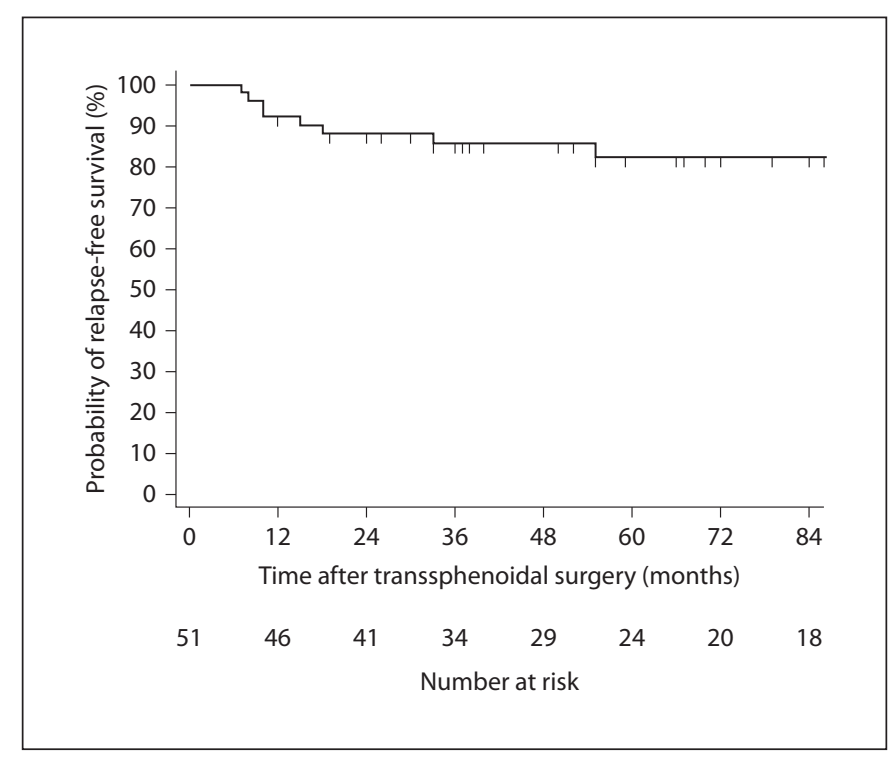

Fig. 2. Kaplan-Meier curve showing relapse-free survival of patients in initial remission after pituitary surgery for CD in the Erasmus Medical Centre Rotterdam, The Netherlands (19912006).

Plasma ACTH (reference 0-11 pmol/l) was measured using a chemiluminescent enzyme immunometric assay (Immulite 2000, Siemens, inter- and intra-assay coefficients of variation, respectively below 6.5 and 5.5\%). Serum 11-deoxycortisol was measured by RIA after extraction (antiserum from Radioassay Systems Labs, Carson, USA; inter- and intra-assay coefficients of variation, respectively below 13 and $12 \%$ ).

\section{Statistical Analysis}

Descriptive statistics were calculated for continuous variables. Sensitivity, specificity, positive predictive value (PPV) and negative predictive value (NPV) were calculated for each test using
$2 \times 2$ tables (patients in sustained remission were compared with patients with early failure of surgery). Relapsing patients were not considered. PPV was defined as the likelihood that a subject with a positive test had persistent $\mathrm{CD}$ after pituitary surgery (treatment failure). NPV was defined as the likelihood that a subject with a negative test would remain in remission after surgery. Cutoff levels were increased stepwise to determine the optimal combination of PPV and NPV. Statistical analysis and graphing were performed using GraphPad Prism version 3.0 (GraphPad Software, San Diego, Calif., USA) and MedCalc version 9.6.3 (MedCalc Software, Mariakerke, Belgium).

\section{Results}

Patient characteristics and test results are shown in table 1. During the study period, 51 patients (65\%) achieved immediate postoperative remission. CD recurred in $20 \%$ of patients after initial successful pituitary surgery (fig. 1). The probability of relapse-free survival of patients in immediate remission after pituitary surgery was $92 \%$ at 12 months, $88 \%$ at 24 months, $86 \%$ at 36 months and $83 \%$ at 84 months (fig. 2). Median time to relapse was 16.5 months (range 7-121). Failure to remove the adenoma completely, resulting in persistent $\mathrm{CD}$, occurred in 28 patients (35\%). These patients received second-line therapy, including repeat pituitary surgery, fractionated stereotactic radiotherapy and/or bilateral adrenalectomy.

Macroadenomas accounted for $43 \%$ in the early failure group. Moreover, in $21 \%$ of early failures no adenoma could be identified on preoperative MRI. In patients successfully operated, the percentage of macroadenomas was only $17 \%$.

Overall, 22 patients $(28 \%)$ were left with partial or complete hypopituitarism. Ten patients in sustained remission (24\%) developed partial or complete hypopituitarism after TS compared with 9 of those with surgical failure (32\%). Deficiency of one or more pituitary hormones was found in $30 \%$ of late relapses ( 3 patients). The thyrotropic axis was most frequently affected (17 patients), followed by gonadotropic (13 patients) and somatotropic (7 patients) axes. Permanent diabetes insipidus occurred in 2 patients.

\section{Morning Serum Cortisol}

Early postoperative morning serum cortisol levels were obtained in 78 patients (fig. 3). Morning serum cortisol levels $<200 \mathrm{nmol} / \mathrm{l}$ were seen in 33 of 40 patients in sustained remission (83\%). Seven patients in sustained remission recorded postoperative morning serum cortisol 
Fig. 3. Morning serum cortisol levels of 78 patients after pituitary surgery for CD. A cutoff level of $200 \mathrm{nmol} / \mathrm{l}$ predicts early failure of surgery in $79 \%$ of patients. All relapses, except one, recorded early postoperative morning serum cortisol levels $>50 \mathrm{nmol} / 1$.

Fig. 4. Peak serum cortisol concentrations of 53 patients in response to human CRH administration after TS for CD. A threshold value of $600 \mathrm{nmol} / \mathrm{l}$ results in a PPV of $78 \%$ for immediate surgical failure (NPV $100 \%)$.
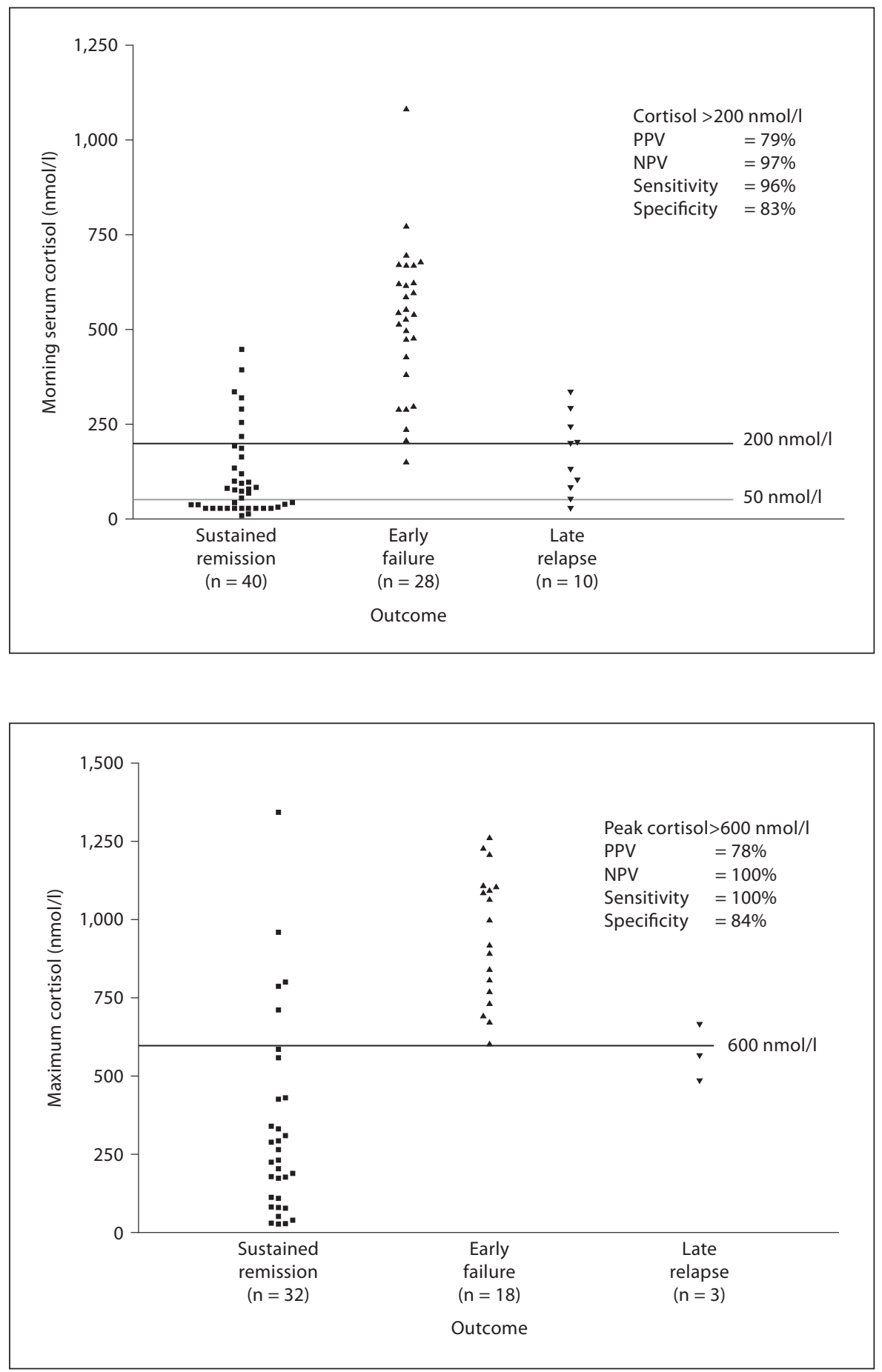

levels in excess of $200 \mathrm{nmol} / \mathrm{l}$ (median follow-up 66 months, range 40-154). Six of these 7 patients had received pretreatment with ketoconazole. Cortisol levels $>200 \mathrm{nmol} / \mathrm{l}$ were seen in $96 \%$ of patients with persistent $\mathrm{CD}$ (early failures). All patients with recurrent $\mathrm{CD}$, except one, had morning serum cortisol concentrations of at least $50 \mathrm{nmol} / \mathrm{l}$. In our series, a threshold value of 200 $\mathrm{nmol} / \mathrm{l}$ for morning serum cortisol obtained within 2 weeks after pituitary surgery resulted in a PPV of $79 \%$ for immediate postoperative failure (NPV 97\%). 
Fig. 5. Early postoperative 11-deoxycortisol levels after metyrapone $(6 \times 750 \mathrm{mg})$ in 72 patients with CD. The metyrapone test has a PPV of $86 \%$ to detect immediate failure of pituitary surgery when a cutoff value of $345 \mathrm{nmol} / \mathrm{l}$ is used (NPV 94\%).

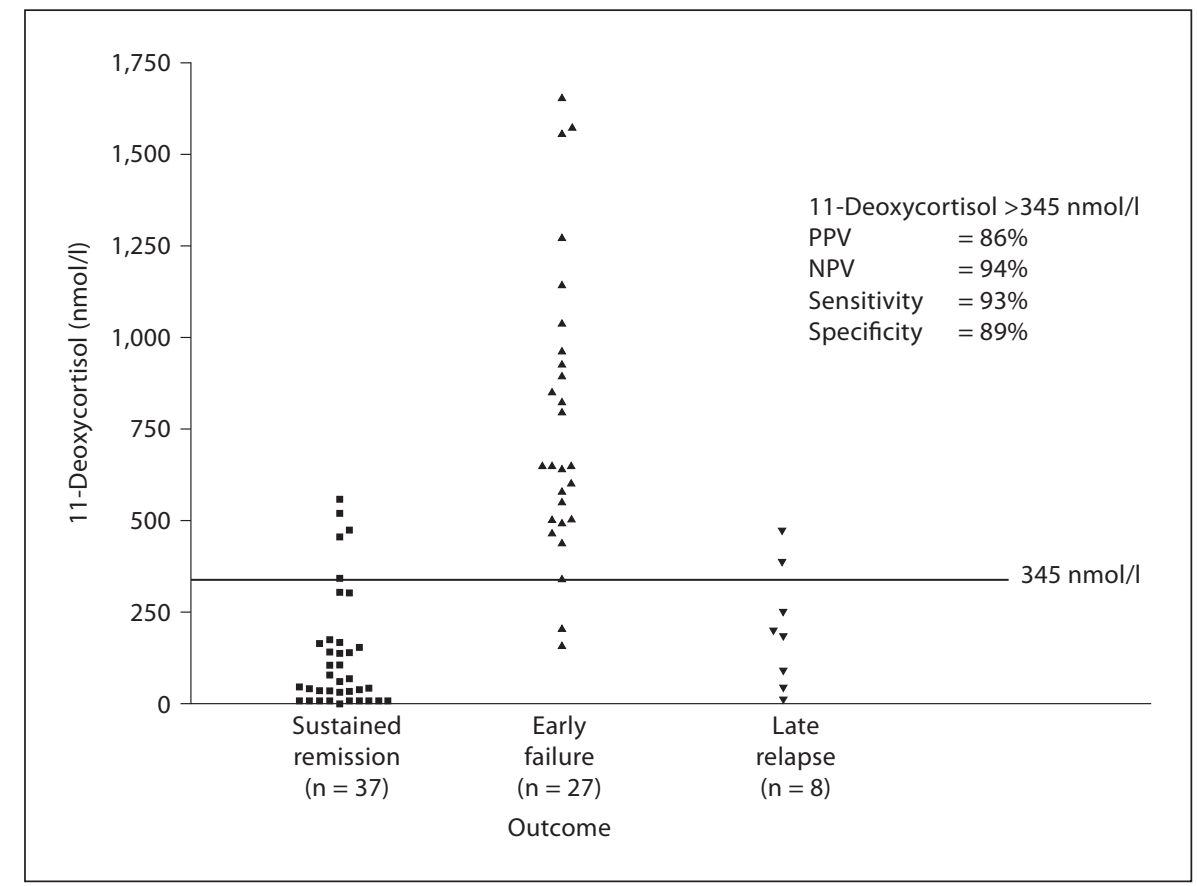

\section{CRH Stimulation Test}

The responsiveness to CRH (human CRH $100 \mu$ i.v.) was studied in 53 patients postoperatively. Results of the CRH stimulation test are shown in figure 4. All patients with persistent hypercortisolism (18 early failures) showed absolute peak cortisol levels $>600 \mathrm{nmol} / \mathrm{l}$ after $\mathrm{CRH}$ administration. Only 5 of 32 patients in sustained remission also had cortisol values in excess of 600 $\mathrm{nmol} / \mathrm{l}$ (median follow-up 55 months, range 40-70). All 5 had received ketoconazole treatment prior to pituitary surgery and also recorded morning serum cortisol concentrations $>200 \mathrm{nmol} / \mathrm{l}$ in the early postoperative phase. All patients with recurrent $\mathrm{CD}(\mathrm{n}=3)$ recorded peak serum cortisol levels $>485 \mathrm{nmol} / \mathrm{l}$ after $\mathrm{CRH}$ administration. In the present study, absolute peak serum cortisol levels $>600 \mathrm{nmol} / \mathrm{l}$ after $\mathrm{CRH}$ predicted immediate surgical failure in 78\% of cases (NPV 100\%). Measurement of plasma ACTH and calculation of the incremental changes in cortisol and ACTH did not improve discrimination between groups (data not shown).

\section{Metyrapone Stimulation Test}

Metyrapone test was performed in 72 subjects. The results of the postoperative metyrapone test are shown in figure $5.89 \%$ of patients in sustained remission (33 out of 37) recorded 11-deoxycortisol levels $<345 \mathrm{nmol} / \mathrm{l}$ after $6 \times 750 \mathrm{mg}$ metyrapone. However, metyrapone-stimu- lated 11-deoxycortisol concentrations of $>345 \mathrm{nmol} / 1$ were seen in 4 patients in sustained remission (median follow-up 77 months, range 55-114); 3 of these 4 patients had been treated with ketoconazole before TS. $93 \%$ of patients with persistent $C D$ after surgery $(n=25)$ noted 11deoxycortisol levels $>345 \mathrm{nmol} / \mathrm{l}$. Although 11-deoxycortisol levels ranged from 12 to $470 \mathrm{nmol} / \mathrm{l}$ in patients with recurrent disease after apparent remission, the majority of patients $(75 \%)$ had 11-deoxycortisol concentrations of $<345 \mathrm{nmol} / \mathrm{l}$. In the present study, serum 11-deoxycortisol levels of $>345 \mathrm{nmol} / 1$ in response to metyrapone predicted early failure of TS in $86 \%$ of cases (NPV 94\%).

\section{Combined Assessment}

In 49 patients (29 patients in sustained remission, 18 early failures, and 2 relapses) all three postoperative tests were performed (morning serum cortisol, CRH test, and metyrapone test). Of the 29 patients in sustained remission who underwent all three tests, 12 recorded postoperative morning serum cortisol levels $<50 \mathrm{nmol} / \mathrm{l}$. All of these 12 patients with 'undetectable' postoperative cortisol concentrations showed relative unresponsiveness to $\mathrm{CRH}$ stimulation, with peak cortisol concentrations ranging from 28 to $80 \mathrm{nmol} / \mathrm{l}$. Furthermore, all 12 also showed an impaired response to metyrapone administration with serum 11-deoxycortisol levels varying from 10 to $78 \mathrm{nmol} / \mathrm{l}$. 
Only 1 patient in the early failure group measured a postoperative morning serum cortisol level $(152 \mathrm{nmol} / \mathrm{l})$ below the cutoff value of $200 \mathrm{nmol} / \mathrm{l}$. She also recorded an insufficient response to metyrapone administration (11-deoxycortisol $208 \mathrm{nmol} / \mathrm{l})$. In the CRH test however, she showed a significant cortisol response $(677 \mathrm{nmol} / \mathrm{l})$ exceeding the cutoff point of $600 \mathrm{nmol} / \mathrm{l}$.

Two patients with recurrent CD underwent all three postoperative tests. One patient had a suppressed morning serum cortisol value of $51 \mathrm{nmol} / \mathrm{l}$ and reached an absolute serum cortisol peak concentration of $485 \mathrm{nmol} / \mathrm{l}$ in the $\mathrm{CRH}$ test. Response in the postoperative metyrapone test was also subnormal (11-deoxycortisol $200 \mathrm{nmol} / \mathrm{l}$ ). The second patient with recurrent disease had a postoperative morning cortisol value of $386 \mathrm{nmol} / \mathrm{l}$ and also showed a substantial response in both CRH test (peak cortisol $568 \mathrm{nmol} / \mathrm{l}$ ) and metyrapone test (11-deoxycortisol $470 \mathrm{nmol} / \mathrm{l})$.

\section{Discussion}

The ultimate goal of a selective transsphenoidal adenomectomy in CD is a complete removal of the corticotropic adenoma without causing loss of normal pituitary functions. After TS, however, a substantial number of patients have persistent CD or develop recurrent tumors during follow-up. We examined early and late outcome of pituitary surgery as well as predictive values of early postoperative tests in a large cohort of patients with CD during a median follow-up period of 84 months.

\section{Early and Late Outcome of Pituitary Surgery}

The immediate postoperative and overall remission rates in the current paper fall at the lower end of the reported outcome data from other centers [4-12, 27]. This may be explained by a number of reasons. Firstly, variability in remission rates can be attributed to the different criteria used to define postoperative remission. We used adequate suppression of serum cortisol after $1 \mathrm{mg}$ overnight dexamethasone in combination with a normal UFC excretion as definition of biochemical remission. Thus, remission or failure were defined independently of the tests that were examined. Secondly, there is considerable difference in duration of follow-up between published studies. Prolonged follow-up leads to lower cure rates, as the incidence of relapse increases with time. In our study, recurrent $C D$ occurred $>10$ years after initially successful pituitary surgery in 1 patient, indicating that lifelong follow-up of patients with CD is mandatory. Thirdly, we re- port the surgical outcome of a heterogeneous group of adenomas, i.e. both micro- and macroadenomas, whereas some clinical series only report results of TS in microadenomas $[4,27]$. Remission rates are lower in patients with macroadenomas $[1,28,29]$. This finding is confirmed in the present survey in which $43 \%$ of patients with surgical failure had a corticotropic macroadenoma. Finally, extensive surgical exploration, as performed in some centers, may result in higher cure rates. However, this is at the expense of postoperative pituitary function loss. Hypopituitarism after pituitary surgery is associated with an impaired health-related quality of life [30, 31]. The trend towards more conservative surgery in our center, aimed at preserving pituitary functions, has resulted in a relatively favorable hypopituitarism rate. Overall, we found $28 \%$ of patients to have postoperative hormonal disturbances compared to $26-52 \%$ reported elsewhere $[11,15,16,32]$.

\section{Prediction of Surgical Outcome}

Which biochemical parameters most reliably predict the long-term outcome after TS is still a matter of debate. Immediate postoperative recognition of patients with persistent $\mathrm{CD}$ or at risk for relapse would allow additional therapeutic measures to be undertaken at an early stage. When judged by long-term outcome, a postoperative serum cortisol level $<50 \mathrm{nmol} / \mathrm{l}$ has been regarded as the best predictor for long-term remission and is associated with a 10 -year recurrence rate of approximately $10 \%$ $[1,6,12-16,33]$. This finding was confirmed in the present study in which remissions were associated with suppressed morning serum cortisol levels. $89 \%$ of relapses recorded postoperative morning cortisol levels $>50$ $\mathrm{nmol} / \mathrm{l}$. Thus, persistently detectable serum cortisol concentrations in the early postoperative phase can be indicative of incomplete resection of the corticotropic adenoma and an increased risk of recurrence. It must be emphasized, however, that detectable morning cortisol levels $(>50 \mathrm{nmol} / \mathrm{l})$ are not necessarily followed by recurrence of $\mathrm{CD}$, which might in part be explained by preoperative treatment with ketoconazole (see below). Moreover, our study confirms that relapse can occur even in the presence of postoperative hypocortisolism.

The CRH test is a widely used non-invasive test to discriminate CD from Cushing's syndrome due to ectopic ACTH secretion [34-36]. Both ovine and human CRH have been used in clinical studies, although there is no consensus on the response criteria. In the current survey, we studied the results of the early postoperative human $\mathrm{CRH}$ test. Compared to peak ACTH level and incremen- 
tal changes in cortisol and ACTH concentration, the absolute peak cortisol concentration after $\mathrm{CRH}$ stimulation gave the best diagnostic accuracy in predicting outcome of pituitary surgery. All failures and recurrences showed a significant rise in serum cortisol during the time course of the test using a cutoff value of $600 \mathrm{nmol} / \mathrm{l}$. In accordance with previously reported literature, we found that suppressed responses to $\mathrm{CRH}$ during the early postoperative period are indicative of long-term remission of CD $[6,7,18-21]$. However, similar to morning cortisol levels, a subset of patients who were in sustained remission exhibited post-CRH cortisol levels $>600 \mathrm{nmol} / \mathrm{l}$ which may in part be related to ketoconazole treatment before TS (see below).

Metyrapone blocks cortisol synthesis by competitively inhibiting $11 \beta$-hydroxylation in the adrenal cortex. This stimulates ACTH secretion, leading to increased production of cortisol precursors such as 11-deoxycortisol. Therefore, the metyrapone test can be used in establishing the diagnosis of secondary adrenal insufficiency [3739]. We studied the results of the metyrapone test carried out in patients after pituitary surgery for $\mathrm{CD}$ in order to establish its usefulness in the assessment of surgical outcome. Postoperatively, the majority of patients with persisting CD had markedly increased levels of metyrapone-stimulated 11-deoxycortisol compared to patients in sustained remission. Previously, van Aken et al. [17] reported in a small number of patients $100 \%$ sensitivity for the early postoperative metyrapone test in detecting patients at risk for recurrent $\mathrm{CD}$ when an 11-deoxycortisol cutoff value of $150 \mathrm{nmol} / \mathrm{l}$ was used. However, in the present study, we found great variability of 11-deoxycortisol levels in patients with recurrent $\mathrm{CD}$, ranging from 12 to $470 \mathrm{nmol} / \mathrm{l}$. Therefore, according to the current data, the usefulness of the metyrapone test in the early prediction of relapse is limited.

Combining the results of all three postoperative tests (serum cortisol, CRH test, and metyrapone test) we found that patients in sustained remission with suppressed postoperative morning serum cortisol concentrations also showed a relative concordant unresponsiveness to $\mathrm{CRH}$ stimulation and metyrapone administration. Comparison of PPVs and NPVs of the investigated tests shows that the additional value of $\mathrm{CRH}$ and metyrapone testing to measurement of morning serum cortisol levels is limited.

\section{Pretreatment with Cortisol-Lowering Drugs}

$\mathrm{CD}$ is associated with diabetes, hypertension, poor wound healing, hemorrhagic diathesis and increased tis- sue fragility. In order to control hypercortisolemia and minimize perioperative risks, medical therapy with ketoconazole prior to surgery is used in several centers. In previous studies on postoperative biochemical testing in $\mathrm{CD}$, results have not been interpreted in relation to eventual preoperative treatment with cortisol-lowering drugs $[7,12,32]$. In the present study, $75 \%$ of patients were pretreated with ketoconazole. Interestingly, 6 of the 7 patients in sustained remission with postoperative serum cortisol levels $>200 \mathrm{nmol} / \mathrm{l}$ received presurgical treatment with ketoconazole. It is possible that these patients, after an apparent remission, will ultimately develop recurrence of CD. However, the median follow-up of these patients was 5.5 years, making recurrent $C D$ in future still possible but less likely. However, an alternative explanation is that the treatment with ketoconazole prior to surgery could have resulted in higher postoperative basal and $\mathrm{CRH}$-stimulated cortisol levels in these patients due to early recovery of suppressed non-tumor corticotropic cells and subsequent restoration of pituitary-adrenal function. Future studies should investigate the possible relationship between preoperative achievement and duration of normocortisolism after ketoconazole pretreatment and the postoperative recovery of the pituitary-adrenal axis.

\section{Conclusions}

In our study we identified undetectable morning serum cortisol concentrations and an impaired responsiveness to $\mathrm{CRH}$ and metyrapone stimulation in the early postoperative period as biochemical predictors of longterm remission. Recurrent CD seems to be associated with higher morning serum cortisol levels and an unsuppressed CRH-stimulated cortisol response. However, there is considerable overlap between patients who do and those who do not relapse. In our series we could not clearly identify the benefits of performing additional $\mathrm{CRH}$ and/or metyrapone tests in the postoperative assessment of patients with CD. In addition, pretreatment with cortisol-lowering drugs may influence the results of different postoperative biochemical tests. Future studies are necessary to determine the effects of preoperative ketoconazole treatment on the recovery of the hypothalamic-pituitary-adrenal axis in patients who are in remission after pituitary surgery. 


\section{References}

$>1$ Biller BM, Grossman AB, Stewart PM, 12 Pereira AM, Van Aken MO, Van Dulken H, Melmed S, Bertagna X, Bertherat J, Buchfelder M, Colao A, Hermus AR, Hofland LJ, Klibanski A, Lacroix A, Lindsay JR, NewellPrice J, Nieman LK, Petersenn S, Sonino N, Stalla GK, Swearingen B, Vance ML, Wass JA, Boscaro M: Treatment of ACTH-dependent Cushing's syndrome: a consensus statement. J Clin Endocrinol Metab 2008;93: 2454-2462.

$>2$ Joshi SM, Cudlip S: Transsphenoidal surgery. Pituitary 2008;11:353-360.

$>3$ Kelly DF: Transsphenoidal surgery for Cushing's disease: a review of success rates, remission predictors, management of failed surgery, and Nelson's syndrome. Neurosurg Focus 2007;23:E5.

4 Patil CG, Prevedello DM, Lad SP, Vance ML, Thorner MO, Katznelson L, Laws ER Jr: Late recurrences of Cushing's disease after initial successful transsphenoidal surgery. J Clin Endocrinol Metab 2008;93:358-362.

$>5$ Joshi SM, Hewitt RJ, Storr HL, Rezajooi K, Ellamushi H, Grossman AB, Savage MO, Afshar F: Cushing's disease in children and adolescents: 20 years of experience in a single neurosurgical center. Neurosurgery 2005;57: 281-285.

$\checkmark 6$ Bochicchio D, Losa M, Buchfelder M: Factors influencing the immediate and late outcome of Cushing's disease treated by transsphenoidal surgery: a retrospective study by the European Cushing's Disease Survey Group. J Clin Endocrinol Metab 1995;80: 3114-3120.

7 Invitti C, Pecori Giraldi F, De Martin M, Cavagnini F: Diagnosis and management of Cushing's syndrome: results of an Italian multicentre study. Study Group of the Italian Society of Endocrinology on the Pathophysiology of the Hypothalamic-Pituitary-Adrenal Axis. J Clin Endocrinol Metab 1999;84: 440-448.

$>8$ Tindall GT, Herring CJ, Clark RV, Adams DA, Watts NB: Cushing's disease: results of transsphenoidal microsurgery with emphasis on surgical failures. J Neurosurg 1990;72: 363-369.

9 Chee GH, Mathias DB, James RA, KendallTaylor P: Transsphenoidal pituitary surgery in Cushing's disease: can we predict outcome? Clin Endocrinol (Oxf) 2001;54:617626.

-10 Atkinson AB, Kennedy A, Wiggam MI, McCance DR, Sheridan B: Long-term remission rates after pituitary surgery for Cushing's disease: the need for long-term surveillance. Clin Endocrinol (Oxf) 2005;63:549-559.

$\checkmark 11$ Rees DA, Hanna FW, Davies JS, Mills RG, Vafidis J, Scanlon MF: Long-term follow-up results of transsphenoidal surgery for Cushing's disease in a single-centre using strict criteria for remission. Clin Endocrinol (Oxf) 2002;56:541-551. Schutte PJ, Biermasz NR, Smit JW, Roelfsema F, Romijn JA: Long-term predictive value of postsurgical cortisol concentrations for cure and risk of recurrence in Cushing's disease. J Clin Endocrinol Metab 2003;88:58585864.

13 Esposito F, Dusick JR, Cohan P, Moftakhar P, McArthur D, Wang C, Swerdloff RS, Kelly DF: Clinical review: early morning cortisol levels as a predictor of remission after transsphenoidal surgery for Cushing's disease. J Clin Endocrinol Metab 2006;91:7-13.

$\checkmark 14$ Estrada J, Garcia-Uria J, Lamas C, Alfaro J, Lucas T, Diez S, Salto L, Barcelo B: The complete normalization of the adrenocortical function as the criterion of cure after transsphenoidal surgery for Cushing's disease. J Clin Endocrinol Metab 2001;86:5695-5699.

15 Trainer PJ, Lawrie HS, Verhelst J, Howlett TA, Lowe DG, Grossman AB, Savage MO, Afshar F, Besser GM: Transsphenoidal resection in Cushing's disease: undetectable serum cortisol as the definition of successful treatment. Clin Endocrinol (Oxf) 1993;38: 73-78.

16 Yap LB, Turner HE, Adams CB, Wass JA: Undetectable postoperative cortisol does not always predict long-term remission in Cushing's disease: a single-centre audit. Clin Endocrinol (Oxf) 2002;56:25-31.

17 Van Aken MO, De Herder WW, Van Der Lely AJ, De Jong FH, Lamberts SW: Postoperative metyrapone test in the early assessment of outcome of pituitary surgery for Cushing's disease. Clin Endocrinol (Oxf) 1997;47:145-149.

18 Avgerinos PC, Chrousos GP, Nieman LK, Oldfield EH, Loriaux DL, Cutler GB Jr: The corticotropin-releasing hormone test in the postoperative evaluation of patients with Cushing's syndrome. J Clin Endocrinol Metab 1987;65:906-913.

19 Pieters GF, Hermus AR, Meijer E, Smals AG, Kloppenborg PW: Predictive factors for initial cure and relapse rate after pituitary surgery for Cushing's disease. J Clin Endocrinol Metab 1989;69:1122-1126.

20 Schrell U, Fahlbusch R, Buchfelder M, Riedl S, Stalla GK, Muller OA: Corticotropin-releasing hormone stimulation test before and after transsphenoidal selective microadenomectomy in 30 patients with Cushing's disease. J Clin Endocrinol Metab 1987;64:1150 1159.

21 Vignati F, Berselli ME, Loi P: Early postoperative evaluation in patients with Cushing's disease: usefulness of ovine corticotropinreleasing hormone test in the prediction of recurrence of disease. Eur J Endocrinol 1994; 130:235-241.

22 Hardy J: Transsphenoidal microsurgery of the normal and pathological pituitary. Clin Neurosurg 1969;16:185-217.
23 Oldfield EH, Doppman JL, Nieman LK, Chrousos GP, Miller DL, Katz DA, Cutler GB Jr, Loriaux DL: Petrosal sinus sampling with and without corticotropin-releasing hormone for the differential diagnosis of Cushing's syndrome. N Engl J Med 1991;325:897905 .

24 Antimicrobial prophylaxis in neurosurgery and after head injury. Infection in Neurosurgery Working Party of the British Society for Antimicrobial Chemotherapy. Lancet 1994; 344:1547-1551.

-25 Van Aken MO, De Marie S, Van Der Lely AJ, Singh R, Van Den Berge JH, Poublon RM, Fokkens WJ, Lamberts SW, De Herder WW: Risk factors for meningitis after transsphenoidal surgery. Clin Infect Dis 1997;25:852856.

26 Spark RF: Simplified assessment of pituitary-adrenal reserve. Measurement of serum 11-deoxycortisol and cortisol after metyrapone. Ann Intern Med 1971;75:717-723.

27 Prevedello DM, Pouratian N, Sherman J, Jane JA Jr, Vance ML, Lopes MB, Laws ER Jr: Management of Cushing's disease: outcome in patients with microadenoma detected on pituitary magnetic resonance imaging. J Neurosurg 2008;109:751-759.

28 Woo YS, Isidori AM, Wat WZ, Kaltsas GA, Afshar F, Sabin I, Jenkins PJ, Monson JP, Besser GM, Grossman AB: Clinical and biochemical characteristics of adrenocorticotropin-secreting macroadenomas. J Clin Endocrinol Metab 2005;90:4963-4969.

29 Swearingen B, Biller BM, Barker FG 2nd, Katznelson L, Grinspoon S, Klibanski A, Zervas NT: Long-term mortality after transsphenoidal surgery for Cushing disease. Ann Intern Med 1999;130:821-824.

30 Van Aken MO, Pereira AM, Biermasz NR, Van Thiel SW, Hoftijzer HC, Smit JW, Roelfsema F, Lamberts SW, Romijn JA: Quality of life in patients after long-term biochemical cure of Cushing's disease. J Clin Endocrinol Metab 2005;90:3279-3286.

31 Feldt-Rasmussen U, Abs R, Bengtsson BA, Bennmarker $\mathrm{H}$, Bramnert M, HernbergStahl E, Monson JP, Westberg B, Wilton P, Wuster C: Growth hormone deficiency and replacement in hypopituitary patients previously treated for acromegaly or Cushing's disease. Eur J Endocrinol 2002;146:67-74.

32 Netea-Maier RT, Van Lindert EJ, Den Heijer M, Van Der Eerden A, Pieters GF, Sweep CG, Grotenhuis JA, Hermus AR: Transsphenoidal pituitary surgery via the endoscopic technique: results in 35 consecutive patients with Cushing's disease. Eur J Endocrinol 2006;154:675-684.

33 Mullan KR, Atkinson AB: Endocrine clinical update: where are we in the therapeutic management of pituitary-dependent hypercortisolism? Clin Endocrinol (Oxf) 2008;68: 327-337. 
34 Newell-Price J, Morris DG, Drake WM, Korbonits M, Monson JP, Besser GM, Grossman AB: Optimal response criteria for the human CRH test in the differential diagnosis of ACTH-dependent Cushing's syndrome. J Clin Endocrinol Metab 2002;87:1640-1645.

35 Reimondo G, Paccotti P, Minetto M, Termine A, Stura G, Bergui M, Angeli A, Terzolo $\mathrm{M}$ : The corticotrophin-releasing hormone test is the most reliable noninvasive method to differentiate pituitary from ectopic ACTH secretion in Cushing's syndrome. Clin Endocrinol (Oxf) 2003;58:718-724.
6 Nieman LK, Oldfield EH, Wesley R, Chrousos GP, Loriaux DL, Cutler GB Jr: A simplified morning ovine corticotropin-releasing hormone stimulation test for the differential diagnosis of adrenocorticotropin-dependent Cushing's syndrome. J Clin Endocrinol Metab 1993;77:1308-1312.

37 Courtney CH, McAllister AS, McCance DR, Hadden DR, Leslie H, Sheridan B, Atkinson $\mathrm{AB}$ : The insulin hypoglycaemia and overnight metyrapone tests in the assessment of the hypothalamic-pituitary-adrenal axis following pituitary surgery. Clin Endocrinol (Oxf) 2000;53:309-312.
38 Fiad TM, Kirby JM, Cunningham SK, McKenna TJ: The overnight single-dose metyrapone test is a simple and reliable index of the hypothalamic-pituitary-adrenal axis. Clin Endocrinol (Oxf) 1994;40:603-609.

39 Giordano R, Picu A, Bonelli L, Balbo M, Berardelli R, Marinazzo E, Corneli G, Ghigo E, Arvat E: Hypothalamus-pituitary-adrenal axis evaluation in patients with hypothalamo-pituitary disorders: comparison of different provocative tests. Clin Endocrinol (Oxf) 2008;68:935-941. 